\title{
"EXTRINSIC MISREPRESENTATIONS" IN ADVERTISING UNDER SECTION 5(a) OF THE FEDERAL TRADE COMMISSION ACT
}

Throughout its history, the Federal Trade Commission has utilized section 5(a) of the Federal Trade Commission Act $^{1}$ as the vehicle for an extensive campaign against false advertising. ${ }^{2}$ That section authorizes the Commission to prohibit "unfair methods of competition in commerce, and unfair or deceptive acts or practices in commerce." 3

Partly because the Supreme Court has spoken in relatively few deceptive advertising cases, ${ }^{4}$ the law in this area has been in need of clarification. One question has been whether the act's coverage is limited to false statements concerning the merits or qualities of the advertised product, or whether it extends to misrepresentations unrelated to the product itself. Despite language in at least two Supreme Court opinions indicating that the latter is the proper construction of section $5(a)^{5}$ some authorities have insisted that there could be no deception in an advertisement that accu-

138 Stat. 719 (1914), as amended, 15 U.S.C. $\$ 45$ (a) (1964).

2 The Commission's emphasis on the problem of misleading advertisements was completely unforeseen by the framers of the Federal Trade Commission Act; that legislation was enacted for the principal purpose of setting up a federal agency to deal with restraint of trade. Henderson, The Federal Trade Commission 339 (1924). Although the FTC's false advertising program was a "fortuitous by-product rather than the result of a clear legislative design," ibid., it has always occupied a major portion of the Commission's work. In 1916, its first full year of operation, three of the five complaints issued by the Commission were directed against deceptive advertising practices. Millstein, The Federal Trade Commission and False Advertising, 64 CoLUM. L. REv. 439, 451 (1964). The following summary for fiscal years 1958-1961 indicates the extent of the Commission's recent activity in this area:

\begin{tabular}{|c|c|c|c|c|}
\hline & \multicolumn{2}{|c|}{ Complaints Issued } & \multicolumn{2}{|c|}{ Cease and Desist Orders } \\
\hline & $\begin{array}{c}\text { Anti- } \\
\text { monopoly } \\
\text { cases }\end{array}$ & $\begin{array}{c}\text { Deceptive } \\
\text { practices } \\
\text { cases }\end{array}$ & $\begin{array}{c}\text { Anti- } \\
\text { monopoly } \\
\text { cases }\end{array}$ & $\begin{array}{c}\text { Deceptive } \\
\text { practices } \\
\text { cases }\end{array}$ \\
\hline $\begin{array}{l}1958 \\
1959 \\
1960 \\
1961\end{array}$ & $\begin{array}{r}86 \\
79 \\
157 \\
120\end{array}$ & $\begin{array}{l}268 \\
271 \\
346 \\
290\end{array}$ & $\begin{array}{r}45 \\
64 \\
57 \\
103\end{array}$ & $\begin{array}{l}228 \\
267 \\
289 \\
265\end{array}$ \\
\hline
\end{tabular}

1960-61 FTC Ann. Rep. 34.

338 Stat 719 (1914), as amended, 15 U.S.C. $\$ 45$ (a) (1964). When enacted in $1914, \S 5$ (a) banned only unfair methods of competition; the phrase dealing with deceptive practices was added by the Wheeler-Lea Amendment in 1938, 52 Stat. 111. Under the original legislation, the FTC's power to prohibit misleading advertisements was severely restricted, for the Supreme Court construed $\$ 5(a)$ to prevent the Commission from acting upon a false advertising complaint unless there was evidence of injury to the business of the advertiser's competitors. FTC v. Raladam Co., 283 U.S. 643 (1931). The Wheeler-Lea Amendment was passed to remove this obstacle to the FTC's authority, enabling the Commission to prohibit any advertisement tending to deceive the consuming public. See H.R. REP. No. 1613, 75th Cong., 1st Sess. 3 (1937); S. Rep. No. 221, 75th Cong., 1st Sess. 2 (1937).

${ }^{4}$ For example, only seven deceptive practices cases appear in the Supreme Court Reports covering the terms from 1945 to 1960.

5 FTC v. Algoma Lumber Co., 291 U.S. 67, 78 (1934); FTC. v. Royal Milling Co., 288 U.S. 212,216 (1932); see text accompanying notes 26-29 infra. 
rately depicts the product's substantive properties. ${ }^{6}$ The Supreme Court resolved this uncertainty in FTC v. Colgate-Palmolive Co., ${ }^{7}$ in which it found a television commercial to be deceptive in the manner in which it communicated a truthful product claim. ${ }^{8}$

The commercial involved in the Colgate litigation was designed to illustrate the moisturizing capacity of Rapid Shave shaving cream. The product was applied to a substance that appeared to be sandpaper, and the substance was immediately shaved clean with a single stroke of a razor. The evidence disclosed that Rapid Shave could shave sandpaper only after a soaking period of approximately eighty minutes, and that the material actually shaved in the commercial was not sandpaper but a "mock up" of plexiglass and sand. ${ }^{\circ}$

The FTC ruled that the advertisement contravened section $5(\mathrm{a})$, not only because of its falsification of the product's softening ability, but also because a false prop had been used to convince the viewing audience of the alleged quality. ${ }^{10}$ The Commission maintained that undisclosed simulations could not be employed to establish even a truthful claim of a product's capabilities. ${ }^{11}$ The Colgate-Palmolive Company and the advertising agency that prepared the Rapid Shave commercial ${ }^{12}$ were ordered to cease and desist from:

6 Carter Prods., Inc. v. FTC, 323 F.2d 523 (5th Cir. 1963) ; Colgate-Palmolive Co. v. FTC, 326 F.2d 517 (1st Cir. 1963) ; Colgate-Palmolive Co. v. FTC, 310 F.2d 89 (1st Cir. 1962) ; FTC v. Colgate-Palmolive Co., 380 U.S. 374, 395 (1965) (Harlan, J., dissenting in part) ; Millstein, supra note 2, at 487; Note, 72 YALE L.J. 145 (1962). 7380 U.S. 374 (1965).

8 In the $1960^{\circ}$ s, the Commission has concentrated on the television commercial in its regulation of deceptive practices. See Note, 37 Notre Dame Law. 524, 528-32 (1962).

9 "Mock up" is the trade term for an object used by the producer of a television commercial for the purpose of simulating another object. For example, since ice cream will melt under the strong lights in the television studio, the advertiser often substitutes a mock up of mashed potatoes.

Before the Commission, Colgate contended that the plexiglass mock up was necessary so that the viewer would receive a realistic picture of the demonstration, since sandpaper resembles plain paper when it is depicted on the television screen. But the Commissioners were not convinced that the limitations of the medium justified Colgate's resort to falsehood. Colgate-Palmolive Co., 59 F.T.C. 1452, 1467-68 (1961). (1963).

10 Colgate-Palmolive Co., Trade Reg. Rep. (1961-63 Transfer Binder) \16318

The FTC rendered two opinions in the Colgate case. In its initial decision, the Commission took the extreme position that all television mock ups are illegal. ColgatePalmolive Co., 59 F.T.C. 1452 (1961). Regarding that position as untenable, the First Circuit set aside the cease and desist order against the company and remanded the case to the Commission. Colgate-Palmolive Co. v. FTC, 310 F.2d 89 (1st Cir. 1962). In its 1963 opinion, the Commission qualified its original stand by prohibiting only those mock ups which are used in a "test, experiment or demonstration" that purports to substantiate a claim made for a product. The second cease and desist order, quoted in text at note 13 infra, was also rejected by the court of appeals, Colgate-Palmolive Co. v. FTC, 326 F.2d 517 (1st Cir. 1963), and the Commission sought review in the Supreme Court.

11 Colgate-Palmolive Co., TRADE REg. Rep. (1961-63 Transfer Binder) II 16318, at $21156-57$ (1963).

12 For discussions of the liability of advertising agencies under $\$ 5(\mathrm{a})$, see Carter Prods., Inc. v. FTC, 323 F.2d 523 (5th Cir. 1963); Colgate-Palmolive Co. v. FTC, 310 F.2d 89 (1st Cir. 1962). 
presenting a test, experiment or demonstration that (1) is represented to the public as actual proof of a claim made for the product which is material to inducing its sale, and (2) is not in fact a genuine test, experiment or demonstration being conducted as represented and does not in fact constitute actual proof of the claim, because of the undisclosed use and substitution of a mock-up or prop instead of the product, article, or substance represented to be used therein. ${ }^{13}$

The First Circuit refused to enforce the order, ${ }^{14}$ but the Supreme Court reversed and upheld the Commission's action. ${ }^{15}$ The Supreme Court agreed with the FTC that the undisclosed use of a mock up in a television product demonstration would constitute a deceptive act, regardless of the veracity of the asserted claim. ${ }^{18}$

It is undisputed that not every false statement contained in an advertisement is a material misrepresentation in violation of section $5(\mathrm{a}) .{ }^{17}$ The Commission and the courts realize that the limitations of the various communications media often make it impractical to insist upon a strict interpretation of the word "deceptive." 18 Furthermore, courts attempt to differentiate between impermissible misrepresentations of fact and acceptable "expressions of opinion," and hence the advertiser is permitted a certain amount of exaggeration when selling his merchandise. ${ }^{19}$

The FTC's position is that the prohibited misrepresentations are those which would be material to inducing the consumer to purchase the adver-

13 FTC v. Colgate-Palmolive Co., 380 U.S. 374, 382 (1965).

14 Colgate-Palmolive Co. v. FTC, 326 F.2d 517 (1st Cir. 1963).

15 FTC v. Colgate-Palmolive Co., 380 U.S. 374 (1965).

16 Id. at 390 .

17 The courts have used the adjective "material" to describe those misrepresentations that constitute deception within the meaning of $\$ 5(\mathrm{a})$. The concept of materiality derives from $\S 15$ of the Federal Trade Commission Act, which defines a false advertisement as one which is "misleading in a material respect." 52 Stat. 114 (1938), 15 U.S.C. \$55 (1964). This section is not directly applicable to the Commission's general jurisdiction over advertising as defined in \&5(a). Rather, \$15 relates to a special jurisdiction exercised by the FTC over food, drugs and cosmetics. The Commission might have brought the Colgate case under this special jurisdiction, but it chose to base the complaint on its general jurisdiction. It is the Commission's view, however, that any advertisement that is "false" under $\$ 15$ is also "deceptive" under the more comprehensive provisions of $\$ 5(\mathrm{a})$. Colgate-Palmolive Co., TraDE REg. REP. (1961-63 Transfer Binder) If 16318, at 21156 n.2 (1963).

18 This is particularly true in the case of television advertising. See, e.g., the public statement of the Chairman of the FTC in 1959:

We realize that it is often difficult to impart true life quality to a product when it is photographed for television. . . Obviously, we recognize that it is impossible to photograph ice cream properly under hot lights. If you have to use shaving cream to get the kind of head which is normal on a glass of beer, this probably would not represent a material deception unless, of course, it was carried beyond a reasonable point. If a glass goblet glistens too much, we still aren't likely to be alarmed.

Advertising Age, Nov. 23, 1959, p. 1, col. 2.

19 Gulf Oil Corp. v. FTC, 150 F.2d 106, 109 (5th Cir. 1945). See also Carlay Co. v. FTC, 153 F.2d 493 (7th Cir. 1946); Kidder Oil Co. v. FTC, 117 F.2d 892 (7th Cir. 1941). In the common law of misrepresentation such harmless exaggera- 
tised product. ${ }^{20}$ But at least two circuit courts qualified the Commission's stand by limiting it to untruths that relate to the product itself. ${ }^{21}$ For these courts, if the article received by the customer were exactly as he was led to expect it would be, the advertiser would have complied with the standards established by section 5 (a) ${ }^{22}$ Thus an advertisement would be deceptive only if there were a qualitative difference between the actual product and the advertised one. ${ }^{23}$

It has been suggested, in support of this view of the act, that section 5 (a) requires a specific showing of "injury" to the consumer or to the advertiser's competitors, and that the Rapid Shave commercial produced no conceivable injury to either, since the customer bought a product which was no different from that which he was urged to buy.24 Although the congressional reports used the word "injury" in commenting on the meaning of the second clause of section $5(a),{ }^{25}$ the courts have preferred to rely on a broader meaning of the word "deceptive" rather than develop an injury standard. Surely the concept of injury may be extended beyond mere financial detriment to encompass a situation such as this one, in which the consumer has been duped by the advertiser. Indeed, there is a line of cases reading the word "deceptive," from which the injury standard is claimed to emanate, to protect the consumer from being tricked into buying a product.

In each of these cases, the act was invoked against advertising misstatements that seemed to have no bearing on the merits or qualities of the product. Consequently, none of them rested on the theory that the product received by the consumer was different from that which he thought he was buying. For example, in FTC v. Royal Milling Co., ${ }^{26}$ flour dis-

tion is called "puffing." Dean Prosser declares that the common law regards a statement as puffed only when it is understood by the buyer to be an expression of the seller's opinion, and hence ignored as such by the buyer. Prosser, TorTs $\$ 104$, at 738 (3d ed. 1964). The Commission and the courts have borrowed the term, but it is not clear whether they have borrowed its common-law definition as well.

20 Colgate-Palmolive Co., Trade Reg. Rep. (1961-63 Transfer Binder) $\Uparrow 16318$, at 21156 (1963).

21 Carter Prods., Inc. v. FTC, 323 F.2d 523 (5th Cir. 1963) ; Colgate-Palmolive Co. v. FTC, 326 F.2d 517 (1st Cir. 1963) ; Colgate-Palmolive Co. v. FTC, 310 F.2d 89 (1st Cir. 1962).

22323 F.2d at 528; 310 F.2d at 93-94. Mr. Justice Harlan, dissenting in Colgate, agreed with the First and Fifth Circuits that the act is concerned only with misrepresentations relating to the merits or qualities of the advertised item. He criticized the majority for failing to realize that the proper focus of the statute is not on what is actually taking place in the studio: "If the image... [the viewer] sees on the screen is an accurate reproduction of what he would see with the naked eyes were the experiment performed before him . . there can hardly be a misrepresentation in any legally significant sense." 380 U.S. at 396 . See also Millstein, supra note 2 , at 485-87; Note, 72 YALE L.J. 145 (1962).

23 Ford Motor Co. v. FTC, 120 F.2d 175, 181 (6th Cir.), cert. denied, 314 U.S. 668 (1941).

24 Note, 72 Y ALE L.J. 145 (1962). See also Millstein, supra note 2, at 487.

25 H.R. REP. No. 1613, 75th Cong., 1st Sess. 3 (1937); S. REP. No. 221, 75th Cong., 1st Sess. 2 (1937).

26288 U.S. 212 (1932). 
tributors had falsely advertised that they were millers, implying that they were the original grinders of the flour they were selling. There had been no misrepresentation of the product itself, but the Supreme Court held that the public had been deceived: "If consumers or dealers prefer to purchase a given article because it was made by a particular manufacturer or class of manufacturers, they have a right to do so, and this right cannot be satisfied by imposing upon them an exactly similar article, or one equally as good, but having a different origin." ${ }^{27}$

In FTC v. Algoma Lumber $C_{0 .}{ }^{28}$ a dealer had adopted the name White Pine to describe lumber that was in fact yellow pine. There was testimony that white pine was superior in quality to yellow pine, but the Court stated that even if there were no difference between the two, the dealer was required to reveal the actual source of the lumber so that the consumer could make his own choice: "[T] he public is entitled to get what it chooses, though the choice may be dictated by caprice or by fashion or perhaps by ignorance." 29

Perhaps the clearest example of a deceptive advertising practice having no relation to the merchandise being sold is that involved in FTC $v$. Standard Educ. Soc'y.30 Door to door encyclopedia salesmen were instructed to misinform each person they contacted that he was one of a very few carefully selected individuals to whom a special offer would be extended. The encyclopedia possessed every attribute claimed for it, but the false appeal to the purchaser's pride was found to violate section $5(\mathrm{a}){ }^{31}$

The same conclusion was reached in two cases concerning the sale of used motor oil without a disclosure that the product had been reprocessed. $^{32}$ Both courts acknowledged that there was no difference in quality between unused motor oil and the advertisers' "re-refined" product. But the nondisclosure was ruled deceptive on the ground that the public is entitled to make its own choice, however ill founded that choice might be. ${ }^{33}$ The use of a false testimonial ${ }^{34}$ and the misappropriation of another's

$27 I d$. at 216.

28291 U.S. 67 (1934).

$29 \mathrm{Id}$. at 78.

3086 F.2d 692 (2d Cir. 1936), modified, 302 U.S. 112 (1937).

3186 F.2d at 696. The Supreme Court found that the salesmen had committed an additional deceptive practice in telling the prospective purchaser that he would receive his set of encyclopedias free, and would pay only for an accompanying "extension service." The customer would get everything that he expected, but it was impermissible to represent that the encyclopedia was "free" when its price was included in the price of the extension service. 302 U.S. at 115-17. See also FTC v. Mary Carter Paint Co., 382 U.S. 46 (1965).

32 Kerran v. FTC, 265 F.2d 246 (10th Cir.), cert. denied, 361 U.S. 818 (1959); Mohawk Ref. Corp. v. FTC, 263 F.2d 818 (3d Cir.), cert. denied, 361 U.S. 814 (1959). 33265 F.2d at 248; 263 F.2d at 821. See also Mohawk Ref. Corp., 54 F.T.C. 1071, 1076 (1958).

34 E.g., Niresk Indus., Inc., 55 F.T.C. 1889, 1894 (1959), aff'd, 278 F.2d 337 (7th Cir.), cert. denied, 364 U.S. 883 (1960) (unauthorized use of the Good Housekeeping Seal). 
trade name ${ }^{35}$ are further instances of "extrinsic misrepresentations" proscribed by section $5(\mathrm{a}) .^{36}$

In affirming the cease and desist order issued against Colgate, the Supreme Court classified the mock up demonstration as an extrinsic misrepresentation and rested on the Royal Milling-Algoma principle. ${ }^{37}$ Although this was the best rationale for its conclusion, it was not the only one available to the Court, for it is arguable that the Rapid Shave commercial did misrepresent a substantive property of the product. The implication of the advertisement was that before the consumer's very eyes, Rapid Shave was being subjected to the sandpaper test. ${ }^{38}$ Since the actual experiment was not taking place because of a simulation, the commercial

35 E.g., Niresk Indus., Inc. v. FTC, 278 F.2d 337 (7th Cir.), cert. denied, 364 U.S. 883 (1960) (advertiser prominently displayed the name "Westinghouse" in connection with an electric fryer of which only the thermostat was manufactured by Westinghouse).

36 Misrepresentation of price can also be classified as an extrinsic misrepresentation. See note 31 supra. However, one could argue that although substantive properties of the article have not been falsified as a result of a misstatement of price, there is a close enough relation between price and product quality-in the minds of the consuming public, if not in fact-for price misrepresentation to be construed as "relating" to the product itself. In fact, it might be argued that all of these extrinsic misrepresentations mislead the consumer into attributing to the product qualities which it does not possess. Thus although there might be no difference in quality between flour sold by a miller and that sold by a distributor, or between new and used motor oil, the purchaser might believe that such a difference exists. Indeed, the Supreme Court stressed this very point in Royal Milling:

[A] large number of buyers . . . believe that the price or quality or both are affected to their advantage by the fact that the article is prepared by the original grinder of the grain. The result of respondents' acts is that such purchasers are deceived into purchasing an article which they do not wish or intend to buy, and which they might or might not buy if correctly informed as to its origin.

288 U.S. at $216-17$.

Respondents in Colgate alluded to the foregoing contention in an attempt to establish that the mock up was the first truly extrinsic misrepresentation to be considered by the FTC, and that therefore all prior cases should be distinguished. Brief for Respondent Ted Bates \& Co., p. 26, Brief for Respondent Colgate-Palmolive Co., p. 22, FTC v. Colgate-Palmolive Co., 380 U.S. 374 (1965). The distinction is difficult to perceive, however, for the false statement in the Rapid Shave commercial had an even closer relation to the product than that asserted for the other advertising practices. For the commercial instilled in the viewer the mistaken belief that the claim of supermoisturizing capacity was being sustained by objective verification before his eyes.

A construction of $\S 5$ (a) based on this semantic distinction between "related" and "unrelated" misrepresentations would be unfortunate. Moreover, the cases seem to preclude this reading of the act, for no satisfactory ground has been advanced for distinguishing at least two of the practices held unlawful. Neither the false testimonial nor the selective offer technique involved in Standard Education has any relation to the article being sold. The false testimonial conveys the impression that the product has all of the characteristics that are commonly ascribed to goods endorsed by the particular agency or individual. However, even if the product did possess those characteristics, the false testimonial would still be held a deceptive advertising practice. The false inducement in Standard Education had not the slightest connection with the product. It can only be concluded that $\$ 5(\mathrm{a})$ prohibits any misrepresentation, however unrelated to the product it may be, if it tends to influence the consumer's decision whether to buy.

37380 U.S. at $387-89$.

38 The commercial was deceptive not in its use of a mock up but in its implicit representation that the sandpaper test was performed without the use of false props. 
had ascribed to the product a quality which it did not possess-objective verification, over and above the seller's word, of a product claim.

The majority in Colgate adverted to this argument, ${ }^{39}$ but declined to rest its holding on it. It adopted the Royal Milling-Algoma rationale by choice, therefore, rather than by necesstiy. It included the mock up demonstration in a category of deceptive practices in which a misrepresentation is employed not to build up a product's capabilities, but to break down an "annoying or irrational habit of the buying public." 40 Thus the Court reaffirmed the principle that section 5 (a) protects the consumer from being tricked into buying a product.

The Rapid Shave commercial was designed to dupe a particular member of the television audience-the skeptic. It is a common trait of many individuals to ignore an advertising claim unless it is substantiated by something in addition to the seller's own word. ${ }^{41}$ To combat this tendency, many advertisements resort to such devices as the testimonial-either by a testing agency, a professional expert, a celebrity or the man in the streetor to the comparison demonstration. The television advertiser has discovered that the visual demonstration is a highly effective means of persuading the skeptical viewer that the product actually can perform as represented. ${ }^{42}$

The Colgate-Palmolive Company devised the sandpaper commercial to exploit the viewer's receptivity to the objective demonstration, but the company was forced to substitute the plexiglass mock up for actual sandpaper since the latter cannot accurately be reproduced on the television screen. Consequently, the only way in which the advertiser could attain the desired effect of a dramatic "before your very eyes" demonstration

Respondents insisted that no such representation should be implied, Brief for Respondent Colgate-Palmolive Co., pp. 20-21, FTC v. Colgate-Palmolive Co., 380 U.S. 374 (1965), but the Supreme Court decided otherwise, 380 U.S. at 386. The Court's inference seems indisputable since the very purpose of the demonstration was to provide the doubting viewer with visual proof of a product claim. See notes 41-47 infro and accompanying text.

39380 U.S. at 388 .

$40 \mathrm{Id}$. at $388-89$.

41 It is interesting that the FTC and the Supreme Court felt compelled in Colgate to extend the act's protection to the wary consumer, for $\S 5(a)$ is usually regarded as intended to protect the unwitting public against the ingenious advertising industry. The standard of the consumer's intelligence used to ascertain whether an advertisement has a tendency to deceive is far below tort's "reasonable man" test. The Supreme Court has remarked that the Commission is expected to protect "the trusting as well as the suspicious," FTC v. Standard Educ. Soc'y, 302 U.S. 112, 116 (1937), and one court called for advertising so clear that "wayfaring men, though fools, shall not err therein." General Motors Corp. v. FTC, 114 F.2d 33, 36 (2d Cir. 1940), cert. denied, 312 U.S. 682 (1941).

42 See Dunn, Advertising-Its Role in Modern Marketing 408 (1961). As a result of the Colgate decision, those advertisers whose products or props cannot be realistically depicted in a television demonstration (e.g., because the substance will melt under the strong studio lights or because its image will be distorted on the screen) have been prevented from using one of the industry's more successful selling methods. The Court was aware of this consequence, but was unpersuaded by the advertiser's objections: "All methods of advertising do not equally favor every seller. If the inherent limitations of a method do not permit its use in the way a seller desires, the seller cannot by material misrepresentation compensate for those limitations." 380 U.S. at 391 . 
was through the use of a false prop. Thus the mock up was crucial to the effectiveness of the commercial; the "sell" was directed at those members of the public who needed objective proof, and without the mock up those people would remain unconvinced. Rapid Shave's hypothetical ability to shave sandpaper as portrayed was irrelevant, for only after they were led to believe that this feat was actually being performed before their eyes did many persons decide to buy the product. ${ }^{43}$ The commercial was therefore deceptive in the clearest meaning of that term as it is used in section 5 (a)a false statement cajoled a substantial number of consumers into purchasing an item that they would decline to buy had they known that the statement was untrue. ${ }^{44}$

In oral argument before the Supreme Court, counsel for Colgate contended that the only criterion for judging television advertising under section 5(a) is whether a commercial communicates the truth: "It does not matter how the truth is communicated." 45 As a general rule, this assertion would not be contested. But it does not apply to an advertisement such as the Rapid Shave commercial, where the manner in which the message is communicated is the very crux of the sales pitch. ${ }^{46}$ Indeed, the announcer exclaimed that the sandpaper demonstration would "prove Rapid Shave's supermoisturizing power." 47 Under these circumstances, a misrepresentation of the process by which a truthful message is communicated is no less deceptive than a falsification of the message itself,

43 "[T] he pictorial test of 'Rapid Shave,' proving to any doubting Thomas in the vast audience that 'By golly, it really can shave sandpaper!' was the clinching argument made by the commercials." Colgate-Palmolive Co., 59 F.T.C. 1452, 1466 (1961). The deceptive nature of the commercial may become more evident if one compares its effectiveness with that of the same commercial with the word "simulation" flashed on the television screen. The latter would be much less successful in selling the product to the incredulous viewer, for the impact of a "see for yourself" demonstration would be diminished substantially by the disclosure. As the Commission pointed out, the misrepresentation that no mock up was used enhanced the effectiveness of the "sell." 59 F.T.C. at 1467.

44 Apart from the contention that the consumer was deceived, there is a further objection to the Rapid Shave commercial in its consequences to the advertiser's competitors. Section 5 (a) affords protection to competitor as well as consumer, and that protection includes a prohibition against any advertising misrepresentation that causes a competitor to lose sales that he would have otherwise retained. FTC v. Algoma Lumber Co., 291 U.S. 67, 78 (1934). Thus whether or not the consumer is deceived when his purchasing decisions are influenced by an extrinsic misrepresentation, the latter violates $\$ 5(\mathrm{a})$ through its effect upon competitors.

4533 U.S.L. WeEK 3214 (U.S. Dec. 15, 1964). This, in essence, was the argument made by $\mathrm{Mr}$. Justice Harlan in his dissent in Colgate, see note 22 supra, and by the circuit court, Colgate-Palmolive Co. v. FTC, 310 F.2d 89, 93-94 (1st Cir. 1962).

46 This distinction also has relevance to the Court's finding of an implicit representation. See note 38 stepra. The First Circuit remarked that if the Rapid Shave commercial contained a representation that no mock ups were used, the same would have to be said for any commercial employing a mock up. 326 F.2d at 522-23. But the lower court failed to realize that the finding of an implicit representation was made only because the heart of the advertisement was its holding out of objective proof. Where the advertiser does not rely on the mock up to verify his product's capabilities, the Colgate ruling has no application and there is no material misrepresentation, express or implied.

4759 F.T.C. at 1458 . (Emphasis added.) 
since the tendency of both misstatements is to lure otherwise uninterested individuals to the product.

In prohibiting a misrepresentation, albeit "extrinsic," that was material to inducing sales, the majority in Colgate was simply reading the act to prohibit advertisers from duping the consumer into buying a product. It is doubtful that this construction of section 5(a) could be called novel; at the least it had been an inexplicit premise for the other cases of deceptive practices having no immediate relation to the advertised product. The Colgate Court merely expressed a standard of business practice which had previously been unarticulated, but present nevertheless, in the law of deceptive advertising. 